\title{
Global Systematic Mapping of Road Dust Research from 1906 to 2020: Research Gaps and Future Direction
}

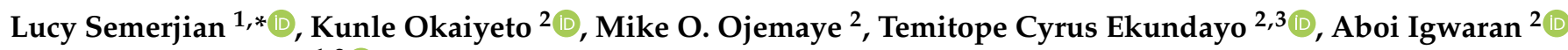 \\ and Anthony I. Okoh 1,2 (D) \\ 1 Department of Environmental Health Sciences, College of Health Sciences, University of Sharjah, \\ Sharjah P.O. Box 27272, United Arab Emirates; aokoh@sharjah.ac.ae \\ 2 SAMRC Microbial Water Quality Monitoring Centre, University of Fort Hare, Private Bag X1314, \\ Alice 5700, South Africa; okaiyetofranciskunle@yahoo.ca (K.O.); MOjemaye@ufh.ac.za (M.O.O.); \\ cyruscyrusthem@gmail.com (T.C.E.); aboi.igwaran@yahoo.com (A.I.) \\ 3 Department of Biological Sciences, University of Medical Sciences, Ondo City PMB 536, Nigeria \\ * Correspondence: 1semerjian@sharjah.ac.ae; Tel.: +971-6505-7426
}

\section{check for} updates

Citation: Semerjian, L.; Okaiyeto, K.; Ojemaye, M.O.; Ekundayo, T.C.; Igwaran, A.; Okoh, A.I. Global Systematic Mapping of Road Dust Research from 1906 to 2020: Research Gaps and Future Direction. Sustainability 2021, 13, 11516. https:/ / doi.org/10.3390/su132011516

Academic Editors:

Efstratios Kelepertzis and

Fotini Botsou

Received: 18 September 2021

Accepted: 12 October 2021

Published: 18 October 2021

Publisher's Note: MDPI stays neutral with regard to jurisdictional claims in published maps and institutional affiliations.

Copyright: (c) 2021 by the authors. Licensee MDPI, Basel, Switzerland. This article is an open access article distributed under the terms and conditions of the Creative Commons Attribution (CC BY) license (https:/ / creativecommons.org/licenses/by/ $4.0 /)$.

\begin{abstract}
Roadside dust resulting from industrialization of society has an adverse effect on the environment and human health. However, despite the global research progress in this field, to date, no bibliometric report on the subject has been documented. Hence, bibliometric mapping is important to assess the quality and quantity of the global research activities on road dust. Data were retrieved from the Web of Science Core Collection and Scopus, while RStudio software was used for data analysis. A total of 1186 publications were retrieved from these databases, and progressive growth in the subject over the last 10 years was observed, considering the positive correlation $(y=0.0024 \times 3-0.1454 \times 2+2.6061 \times-8.5371 ; R 2=0.961)$ obtained for these indices. China had the highest publications, and environmental science-related journals dominated publications on road dust. The findings suggest that other regions of the world, such as the Middle East and Africa, need to channel their research efforts toward this field, considering the shortage of publications on the subject from these regions. Therefore, this study shows that assessing research activity on road dust is important for planning impactful research directions and setting protective and adaptive policies related to the field.
\end{abstract}

Keywords: road dust; heavy metals; bibliometric; industrial development; traffic system

\section{Introduction}

Road transportation is important for sustained and inclusive growth of the economy and plays a key role in increasing social divergence in all nations [1]. When compared to other transport means, road projects improve the economic and societal well-being of people [2]. A good road network can decrease travel time, reduce the costs of transport, and increase income and standard of living; thus, the merits of road transport are indisputable [2]. Regardless of the merits, road transportation activities may constitute adverse effects on the degradation of environmental quality and human health [3]. Anthropogenic activities disrupt the intricate balance among the foregoing constituents of the life support system and have negative consequences on public health [4-6].

Roadside dust, also known as road dust or street dust, is a major source of pollution to the environment, as not only is it just another type of pollution in urban areas, but it is an ideal medium for transferring other contaminants into the environment [7] Roadside dust is composed of settled materials from construction works [8], soil [9], emissions and soot from vehicles and industries [10,11], and airborne particulates [7,12]. Due to its composition and characteristics, it has adverse effects on humans, plants, and animals. Consequently, it has been considered an excellent environmental pollution indicator of the urban environment $[7,13,14]$. The possibility of re-suspension (by repeatedly rising, 
subsiding, and rising again) and the presence of contaminants, such as heavy metals, at low concentrations within the immediate vicinity of humans, plants, and animals makes road dust very hazardous, as these living organisms are directly or indirectly exposed to it, mostly through inhalation [14]. The presence and levels of heavy metals and other contaminants in roadside dust have been linked to emissions from motor vehicles, and this has been observed to vary among urban regions with different human activities and land uses [15]. The distribution of these contaminants in road dust is associated with land use patterns and the population size of the city in which it occurs [13,16]. Due to the effect of vehicular emissions and urban traffic, road dust contains soil particles $<100 \mu \mathrm{m}$ with more negative health effects and environmental hazards than those of soil particles with sizes $<100 \mu \mathrm{m}$, and it is capable of adhering to human skin [17-20].

Contamination of road dust or street dust has greatly increased in urban environments due to industrialization and urbanization within the last three decades [21,22], thereby attracting huge, global interest, hence the extensive studies on the subject $[7,15,23,24]$. Although the research on road dust is gaining attention from different perspectives, such as source identification, concentration profiles, spatial distribution, health risk assessment, and enrichment levels at national and sub-national levels [25-31], there remains a lack of a comprehensive survey of road dust research across these perspective at the global scale.

To understand the interdisciplinary nature of road dust research, publication output related to road dust (or dust) highlights numerous points of difference in ideas and inspires simple conceptualization of probable challenges. Only quantitative data analysis of road dust can define and assess the degrees of publication output on road dust and allow for the establishment of specific goals regarding how to encourage the integration of different disciplines. The quantitative method of data analysis is also helpful in providing a model or baseline for future studies [32]. The use of a bibliometric study is an appropriate method to identify the growth pattern and volume of publications on road dust. Similarly, bibliometric analysis is a suitable approach to identify active researchers, important research themes, and research institutions and countries for future planning, as well as collaboration networks among them on a particular subject or field [33-36].

Thus, researchers need a range of theoretical and practical tools to measure experimental data. Utilizing quantitative analysis, correlation networks, and statistics, the bibliographic and content information of the articles in each field can be analyzed [37]. This statistical method has been employed to quantify research publications on different fields of science, including environmental and public health subjects, such as air pollution and public health [38], sources of atmospheric pollution [39], microplastics in the environment [40], acid rain [41], tuberculosis [42], Alzheimer's disease, [43], HIV / AIDS [44], drinking water research [45], allergy [46], diabetes mellitus and T cells [47], malaria [48], foodborne disease [49], spinal cord injury [50], microbial chlorine resistance in drinking water/water treatment [51], microorganisms' implications in neurodegenerative diseases [52], Plesiomonas-related research [53], organochlorine pesticides [54], bioflocculants [55], diabetes [56], and renewable energy [57], among others.

Despite the tremendous progress in research related to road dust over the past few decades, no bibliometric report has been documented on the quantity or trend of research, nor have the identities of prominent and prolific researchers in the field been revealed. Hence, the present study was carried out to evaluate the global trends in road dust research with the following objectives: (i) to determine the annual scientific publications from 1906 to 2020; (ii) to determine the most prolific authors, institutions, and countries; (iii) to identify relevant documents and sources in road dust research; (iv) to identify the common keywords and trending topics in the subject; and (v) to suggest possible future research directions for road dust research. 


\section{Materials and Methods}

\subsection{Search and Recovery of Data}

The search and recovery of published documents on this subject were carried on the 6 July 2021 using Web of Science (WoS) and Scopus [58]. The WoS database covers the largest number of peer-reviewed publications on science and engineering, and it can serve for in-depth exploration of specialized or interdisciplinary fields [59], while Scopus is the widest citation and abstract database consisting of published literature $[60,61]$. These hybrid databases were employed in the study because of their ease of accessibility and wide coverage of a variety of disciplines [60]. Therefore, to retrieve data related to the subject, we used the following search keywords: TITLE: (road dust*) OR TITLE: (street dust*) OR TITLE: (traffic dust*) with the article search mode on the WoS database. Moreover, the search keywords:(TITLE (road AND dust*) OR TITLE (street AND dust*) OR TITLE (traffic AND dust*)) AND PUBYEAR < 2021 AND (LIMIT-TO (DOCTYPE, "ar")) were recovered on the Scopus database. The search with backdated data between 1 January 1906 and 31 December 2020 was employed for the bibliometric study to retrieve all related publications on the subject. The following documents types were not considered for export in this study: meeting abstracts, corrections, news items, letters, note retractions, and editorial materials [38,62]. Subsequently, documents comprising of articles, proceedings papers, and book chapters were exported for bibliometric analysis. A total of 900 documents were retrieved from WoS, while the search on the Scopus database generated 1091 documents. These data were obtained in Bibtex file format and subjected to bibliometric analysis using RStudio software. RStudio software (version 4.1.0) was employed in this study because it is available freely (https: / / www.rstudio.com/, accessed on 10 October 2021).

\subsection{Processing and Transformation of Data}

RStudio (version 4.1.0) software with a bibliometric package for visualization, tabulation, and systematic mapping of retrieved data was employed for data processing and transformation [63]. Because two different databases (WoS and Scopus) were employed for this study, the possibility of data duplicate was high; as a result, these duplicates of data were eliminated by merging the duplicate data using $R$ codes "duplicated Matching $(M$, Field $=$ "TI", tol $=0.95) "$, resulting in a total of 1186 publications from the two databases. Codes of analysis of research structure including most relevant keywords, most productive country, most relevant sources, annually generated publications, and most productive authors were recovered from https:/ / www.bibliometrix.org (accessed on 10 October 2021). Web of country collaboration, top author's production output over the years, co-citation, and keyword co-occurrence was evaluated and viewed with two-way web algorithms of rectangular matrices.

\section{Results and Discussion}

\subsection{Publication Records of Road Dust Research}

A total of 1186 publications from 380 journals and books with 2930 keywords (plus) (ID) and 2140 authors keywords (DE) (Table 1) were retrieved from the two databases (WoS and Scopus). Out of 2930 authors, 84 reported single-authored publications and 2865 reported multiple-authored publications, resulting in 2.47 author/publication and 0.405 publication/authors values, while the collaborative index was 2.6. This is an indication of the high engagement of multiple authors per publication, thus suggesting the productivity or enhanced interest in this field. For example, an increase in publications reported yearly suggests increasing interest in the field and vice versa. In this study, the number of publications reported was lowest in the year $1906(n=1)$ and highest in the year $2020(n=134)$. 
Table 1. Publication record of studies on road dust recovered from Scopus and WoS databases from 1906 to 2020.

\begin{tabular}{cc}
\hline Publication Information & Records \\
\hline Number of articles & 1186 \\
\hline Sources (journals, books) & 380 \\
\hline Keyword (plus) (ID) & 2930 \\
\hline Author keywords (DE) & 2140 \\
\hline Duration/period & 114 years /1906-2020 \\
\hline Mean values of citation per publication & 3.144 \\
\hline Authors & 2930 \\
\hline Authors' appearances & 5256 \\
\hline Authors of single-authored publication & 65 \\
\hline Authors of multi-authored publications & 2865 \\
\hline Single-authored publication & 84 \\
\hline Publication per author & 0.405 \\
\hline Authors per publication & 2.47 \\
\hline Co-authors per publication & 4.43 \\
\hline Collaboration index & 2.6 \\
\hline
\end{tabular}

Although there were few discrepancies in the number of yearly publications reported, a gradual increase in yearly publications was observed during the studied period (Figure 1). Moreover, the positive correlation $(\mathrm{y}=0.0024 \times 3-0.1454 \times 2+2.6061 \times-8.5371 ; \mathrm{R} 2=0.961)$ obtained when the data were fitted into a polynomial model indicates that more data or publications on this subject could be generated in years to come. It was also observed that scholarly works on road dust have been conducted in the domains of surveillance [29], source apportionment [64], distribution [65,66], and ecological toxicity [19]. The annual growth rate of $8.97 \%$ for published literature within this timeframe further confirms that research on heavy metal pollution in road dust has attracted attention over the years.

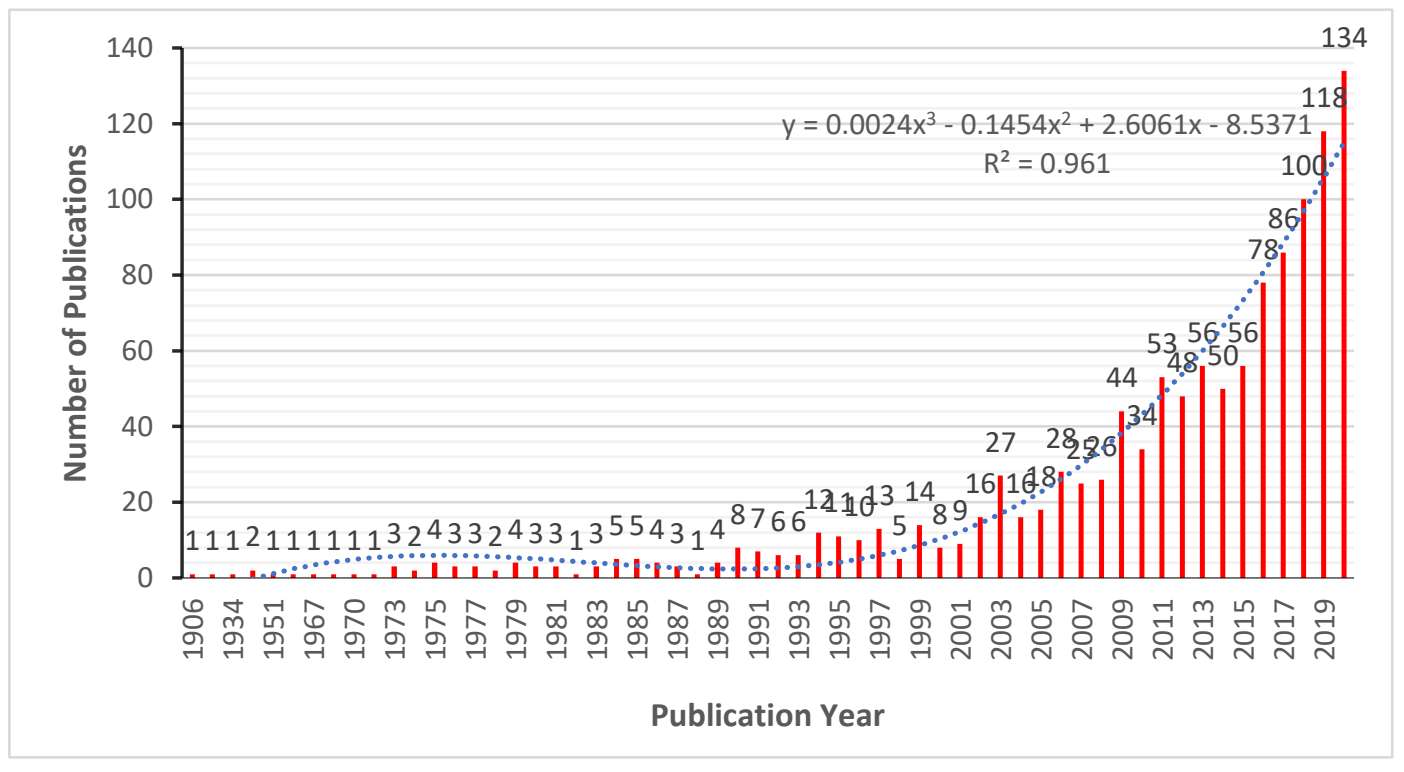

Figure 1. Annual publication record of studies on road dust from 1906 to 2020. 


\subsection{Contributing Countries}

The top 20 leading countries on road dust research from 1906 to 2020 are presented in Table 2. Over 50 countries published reports on this research niche within this period. China, the USA, the United Kingdom, Iran, Japan, India, Turkey, Spain, Germany, and Poland were the top 10 countries with the most research documents on this topic. The publications of these countries accounted for $83.34 \%$ of the total publications across the globe. China was ranked first with 322 publications amounting to $36.45 \%$ of the total publications followed by the USA with 96 publications (10.87\%) and the United Kingdom with 55 publications $(6.23 \%)$. Furthermore, other countries within the top ten brackets include Iran with 48 publications (5.44\%), Japan with 47 publications $(5.32 \%)$, India with 46 publications $(5.21 \%)$, Turkey $(3.96 \%)$, Spain $(3.74 \%)$, Germany $(3.17 \%)$, and Poland $(2.95 \%)$. However, there were slight alterations in ranking when productivity was assessed regarding the number of citations per country. China $(n=9561)$ and the United Kingdom $(n=3384)$ were the two nations with the highest numbers of citations (Table 2). Worthy of note is that no African country made the list of the top 20 nations with the highest number of citations. However, Bahrain $(n=530)$ and Jordan $(n=525)$ are the two countries in the Arabian Peninsula that made the top 20 list of nations with the highest citations, while the UAE, Kuwait, and Oman were not among the top 20 countries. These data are of concern considering the enormous levels of vehicular traffic, industrial emissions, and atmospheric pollution in these countries [67], and this underlines the need for research on this topic in Africa and the Arabian Peninsula. Equally, multiple-country publications and single-country publications, as well as their ratio, were assessed, and single-country publications dominated road dust research as shown in Table 2.

Table 2. Twenty most productive countries in road dust research and overall number of citations per country.

\begin{tabular}{|c|c|c|c|c|c|c|c|c|c|c|c|}
\hline \multicolumn{8}{|c|}{ Most Productive Countries } & \multicolumn{4}{|c|}{ Overall Number of Citations per Country } \\
\hline Position & Country & Publications & $\%$ & Freq & SCP & MCP & MCP_Ratio & Position & Country & $\begin{array}{c}\text { Total } \\
\text { Citations }\end{array}$ & $\begin{array}{l}\text { Average } \\
\text { Citations }\end{array}$ \\
\hline 1 & China & 322 & 36.45 & 0.299257 & 282 & 40 & 0.1242 & 1 & China & 9561 & 29.69 \\
\hline 2 & USA & 96 & 10.87 & 0.089219 & 82 & 14 & 0.1458 & 2 & $\begin{array}{l}\text { United } \\
\text { Kingdom }\end{array}$ & 3384 & 61.53 \\
\hline 3 & $\begin{array}{l}\text { United } \\
\text { Kingdom }\end{array}$ & 55 & 6.23 & 0.051115 & 41 & 14 & 0.2545 & 3 & Spain & 3224 & 97.70 \\
\hline 4 & Iran & 48 & 5.44 & 0.04461 & 30 & 18 & 0.375 & 4 & USA & 1938 & 20.19 \\
\hline 5 & Japan & 47 & 5.32 & 0.04368 & 33 & 14 & 0.2979 & 5 & Japan & 1848 & 39.32 \\
\hline 6 & India & 46 & 5.21 & 0.042751 & 39 & 7 & 0.1522 & 6 & Iran & 1495 & 31.15 \\
\hline 7 & Turkey & 35 & 3.96 & 0.032528 & 34 & 1 & 0.0286 & 7 & India & 1159 & 25.20 \\
\hline 8 & Spain & 33 & 3.74 & 0.030669 & 14 & 19 & 0.5758 & 8 & Turkey & 1113 & 31.80 \\
\hline 9 & Germany & 28 & 3.17 & 0.026022 & 24 & 4 & 0.1429 & 9 & Korea & 790 & 43.89 \\
\hline 10 & Poland & 26 & 2.95 & 0.024164 & 24 & 2 & 0.0769 & 10 & Germany & 765 & 27.32 \\
\hline 11 & Australia & 23 & 2.60 & 0.021375 & 18 & 5 & 0.2174 & 10 & $\begin{array}{c}\text { New } \\
\text { Zealand }\end{array}$ & 765 & 191.25 \\
\hline 12 & Korea & 18 & 2.04 & 0.016729 & 16 & 2 & 0.1111 & 12 & Australia & 755 & 32.83 \\
\hline 13 & Canada & 17 & 1.93 & 0.015799 & 13 & 4 & 0.2353 & 13 & Poland & 658 & 25.31 \\
\hline 14 & Brazil & 14 & 1.59 & 0.013011 & 13 & 1 & 0.0714 & 14 & Greece & 554 & 69.25 \\
\hline 15 & Italy & 14 & 1.59 & 0.013011 & 10 & 4 & 0.2857 & 15 & Italy & 543 & 38.79 \\
\hline 16 & Nigeria & 14 & 1.59 & 0.013011 & 13 & 1 & 0.0714 & 16 & Bahrain & 530 & 106.00 \\
\hline 17 & Jordan & 13 & 1.47 & 0.012082 & 10 & 3 & 0.2308 & 17 & Jordan & 525 & 40.38 \\
\hline 18 & Sweden & 12 & 1.36 & 0.011152 & 10 & 2 & 0.1667 & 18 & Finland & 376 & 41.78 \\
\hline 19 & $\begin{array}{l}\text { Czech } \\
\text { Republic }\end{array}$ & 11 & 1.25 & 0.010223 & 11 & 0 & 0 & 19 & Brazil & 299 & 21.36 \\
\hline 20 & Malaysia & 11 & 1.25 & 0.010223 & 9 & 2 & 0.1818 & 20 & Argentina & 246 & 41.00 \\
\hline
\end{tabular}

SCP—single-country publications; MCP—multiple-country publications; MCP_Ratio_multiple-country publication per publication.

China was observed to be very dominant in all bibliometric indices, indicating the difference between the level of understanding/awareness of China and that of other countries/regions of the word regarding the danger and potential health effects of the exposure, inhalation, and ingestion of, as well as dermal contact with, road dust. For instance, Shi et al. [68] reported elevated concentrations of $\mathrm{Pb}, \mathrm{Cd}, \mathrm{Cu}, \mathrm{Ni}, \mathrm{Zn}$, and $\mathrm{Cr}$ 
(but not $\mathrm{Mn}$ ) in street dust of Xianyang City, China, compared to background soil levels. The report of Yongming et al. [25] highlighted that in comparison with other Chinese soil, urban dust in Xi'an, China, has elevated metal concentrations, except for those of arsenic and manganese. This country has competent researchers and government research funds; hence, the researchers from different institutions within the country may collaborate, and they might not have any reasons to depend on researchers outside their own country for research grants, skills, and publications [69-71].

Examining the soil guideline values of China, Chen et al. [72] revealed that it was only $\mathrm{Cd}$ that had a considerable contamination level in roadside soils in Beijing, China, while those of $\mathrm{Cu}, \mathrm{Zn}$, and $\mathrm{Pb}$ were lesser, and $\mathrm{As}, \mathrm{Ni}$, and $\mathrm{Cr}$ was not detected at all. Similarly, studies conducted by Naderizadeh et al. [73] and Wei et al. [15] have also reported the presence of heavy metal (such as $\mathrm{Pb}, \mathrm{Cu}, \mathrm{Zn}, \mathrm{Cd}, \mathrm{Cr}, \mathrm{Ni}, \mathrm{Mn}, \mathrm{Be}, \mathrm{Co}$, and U) in road-deposited dust in different types of urban environments. Lu et al. [26] reported that in comparison with Chinese soil guidelines, street dust in Baoji, China, has high heavy metal concentrations ( $\mathrm{Pb}, \mathrm{Cu}, \mathrm{Zn}, \mathrm{Ni}$, and $\mathrm{Mn}$ ). Similarly, Aslam et al. [67] documented heavy metals (such as $\mathrm{Pb}, \mathrm{Cd}, \mathrm{Cu}, \mathrm{Zn}, \mathrm{Fe}, \mathrm{Ni}$, and $\mathrm{Mn}$ ) in different roads with varying levels of traffic lights throughout Dubai, the United Arab Emirates. In their study, higher concentrations of heavy metals in road dust with more traffic lights were reported. Moreover, in Bahrain, Madany et al. [74], documented the difference and similarities in the concentration of heavy metals in outdoor road dust and residential indoor dust. The mean concentrations of 742, 1.5, 67, 9.6, and $12 \mathrm{mg} / \mathrm{kg}$, for $\mathrm{Pb}, \mathrm{Cd}, \mathrm{Zn}, \mathrm{Cr}$, and $\mathrm{Ni}$, respectively, were obtained with the major source of metals being vehicle exhaust. In a similar study, Al-rajhl et al. [75] in Riyadh, Saudi Arabia, examined the correlation between metal levels and outdoor road-deposited dust and indoor dust. Heavy metal mean concentrations of $1762 \pm 593,2.5 \pm 0.3,443 \pm 223,35.1 \pm 2.7,93.9 \pm 41.9,43.9 \pm 5.6$, and $4.6 \pm 0.3 \mu \mathrm{g} / \mathrm{g}$, for $\mathrm{Pb}, \mathrm{Cd}, \mathrm{Zn}, \mathrm{Cr}, \mathrm{Cu}, \mathrm{Ni}$, and $\mathrm{Li}$, respectively, were reported. These results indicate that dust samples from the road are heavily contaminated by heavy metals.

This study clearly revealed that about $60 \%$ of the research on road dust comes from developed countries, while low-income countries accounted for a few of the publications on this topic. The reason for this may not be far from the fact that most of the leading research laboratories, institutions, and centers of the world are located in these developed countries [76,77]. Other contributing factors may include adequate government funding, economic prosperity, presence of conducive and sophisticated research environments and laboratories, opportunities for research grants, and opportunities to enjoy short-term research and exchange programs in developed countries [57].

Nevertheless, it can be observed that countries with arid and desert environments in the Middle East (Jordan, Iraq, Oman, Qatar, United Arab Emirates, Yemen, etc.) and some African countries (Algeria, Egypt, Chad, Libya, Mali, Morocco, Niger, Sudan, Tunisia, etc.) facing serious dust pollution are not active in this research area. However, one of the possible reasons that could have prevented African countries from participating in this research is the lack of research funds and support from the government. On the contrary, in the Middle East, research funds might not be the problem, but poor visibility in this research domain could result in it being deemed a low priority.

\subsection{Research Collaboration and Institutions}

Collaboration is an essential part of scientific research, and different patterns of collaboration both shape scientific productivity and characterize individual scientific fields [78]. Research collaboration has been observed to be gaining huge attention amongst scientists worldwide because of the enormous advantage inherent in this research initiative. These advantages include, among others, prompt delivery of research output, improved research quality and output, exchange of research ideas and technology, improved research productivity, and access to human resources and research facilities [79,80]. Moreover, this research initiative permits the joint applications of research funds, the establishment of novel research projects, etc. Collaborations increase the citations of papers, especially if 
there is an international team of authors involved [81]. Scholars must recognize the value of research networking for the goal of increasing productivity, as association with experts in a field bring about creative and innovative thinking and ideas. Therefore, collaboration should be the aim of every researcher and institution because it enables capacity building and offers multiple opportunities to surpass limitations that arise within a single institution and due to scarce resources [82]. As a result of the numerous advantages of collaboration, funding bodies, including government agencies, industries, and research institutions, are encouraging collaborations within the scientific communities by deliberately including the clause for research collaboration in their calls for grants before researchers can access their funds/grants [57].

Enhanced access to sophisticated and hyphenated analytical instruments and the availability of reference standards for metals and solvents are another important reason for collaboration on research related to heavy metal burdens in road dust. In the present study, although a total of 1186 publications were retrieved from the two databases (WoS and Scopus) on road dust, the top 20 countries generated 883 publications out of which 726 publications $(82.22 \%)$ were from a single country and 416 publications (17.78\%) involved inter-country publications (Table 2). For example, China reported 282 single-country publications and 40 multiple-countries publications, the USA published 82 single country papers and 14 inter-country research documents, and the United Kingdom reported 41 intra-country research documents and 14 inter-country publications. Surprisingly, there were no countries located in the Arabian Peninsula among the top 20 countries with the most collaborations on road dust research as single-country publications or multiplecountry publications.

Figure 2 depicts research collaborations on road dust research among the top 20 countries. Lines are routes that connect these countries and are employed for knowledge map visualization [83]. The line connections represent the number of collaborations among countries and the line thickness indicates the strength/frequency of the collaboration. It is evident from Figure 2 that China and the United Kingdom were the countries with the highest collaboration on the subject with 21 connection lines each to other countries. China's strongest connection was with the USA, Canada, Germany, and Australia. The USA (with 20 connection lines) had the third highest collaborative strength. The collaborative advantage of China over other countries of the world other than the United Kingdom may be related to the setting up of different funding and travel schemes/programs by the Government of China for Chinese scientists. Examples of these schemes/programs are the "Framework Program" and "Thousand Talent Program, Horizon 2020"; these are programs financed by both China and the European Union (https: / /www.enago.com/academy / chinese-scientists-increase-global-research-collaboration/, accessed on 13 October 2021).

The most relevant institutions in road dust research are presented in Figure 3. Our analysis revealed that the University of Tokyo, Japan, is the most productive institution on road dust research with 36 publications. Shaanxi Normal University, China, and the University Nacl Autonoma, Mexico, were ranked second and third with 24 and 22 publications, respectively. The fourth- and fifth-ranked institutions in road dust research are Shiraz University, Iran $(n=21)$, and Beijing Normal University, China $(n=20)$. These institutions make up the five most productive institutions on road dust research globally, and they accounted for $38.80 \%$ of the first twenty institutions with the highest publications on road dust-related research indexed in both Scopus and WoS databases. It can be observed that the Chinese institutions dominated the top twenty institutions in regard to road dust research (Figure 3), and this result corroborates our observations of some of the bibliometric indices previously reported in Figure 1. 


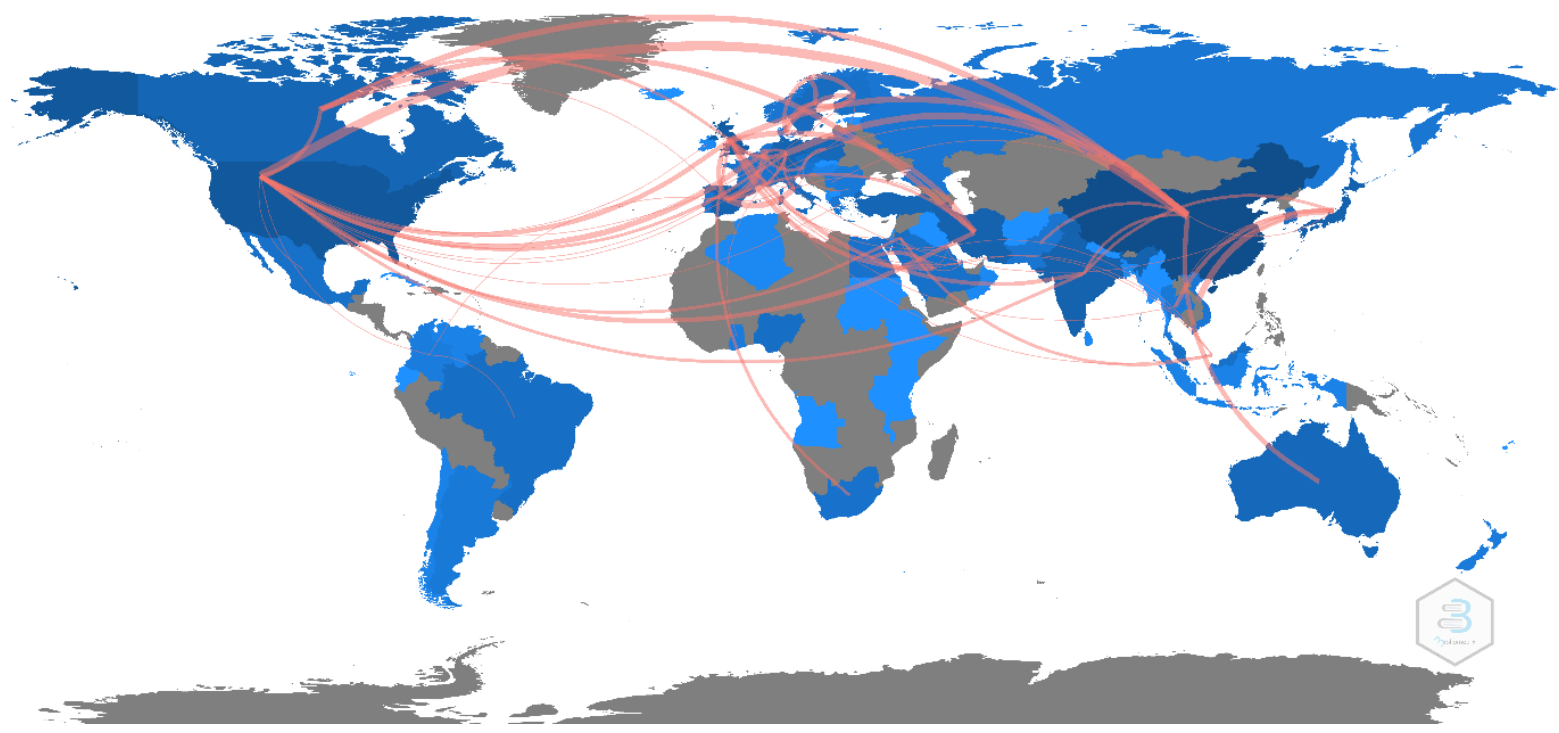

Figure 2. Collaboration visualization map of the top 20 countries researching road dust (lines connecting countries indicate frequency of collaboration and line thickness shows strength of collaboration).

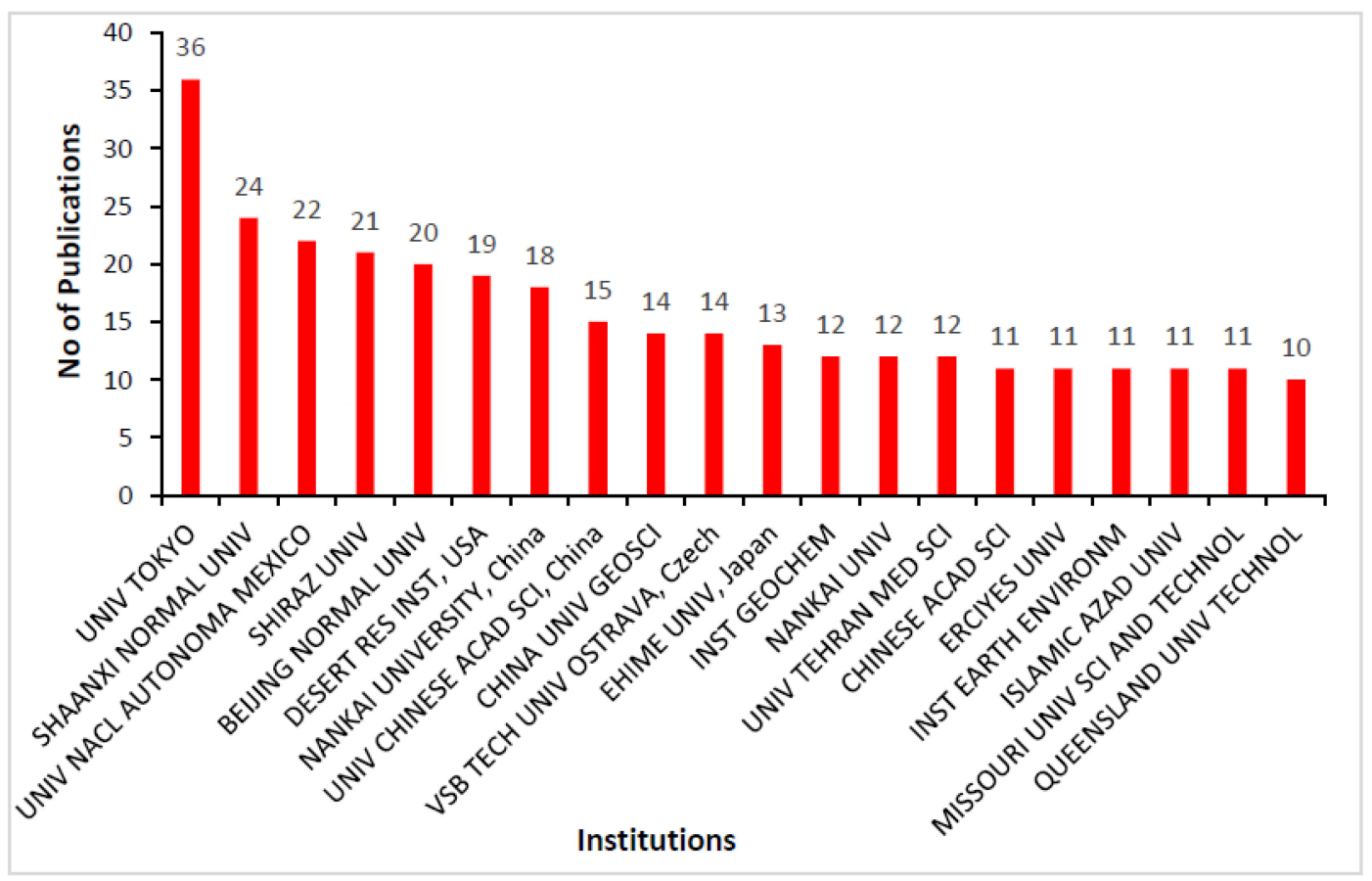

Figure 3. Top 20 research institutions in regard to road dust research from 1906 to 2020.

\subsection{Analysis of Keywords}

Table 3 presents a list of keywords related to research on road dust. It can be observed that author keywords were employed to assess the trend in research associated with road dust. This analysis is important as keywords in scientific publications are used to determine the state of a research area. In addition, it can be used as an indicator of the research hotspot in a given field [77]. In addition, keywords help to identify relevant themes in research publications. This is the reason editors of journals require authors to include in their manuscripts five to seven keywords before submission of their papers for peer review. In this study, the relevant themes related to this research area, including road dust, street dust, heavy metal(s), dust, health risk assessment, pm10, PAH, health risk, pollution, and source apportionment, are presented in Table 3. The keyword with the highest citation 
was road dust, showing up in 280 publications. Street dust showed up in 223 publications in the keywords, while heavy metals was observed in 125 publications. The term "heavy metals" over the past 20 years has been consistently employed in various articles and reports relating to chemical hazards and safe handling of chemical compounds. It is usually referred to as the group name for metalloids and metals that are linked to pollution and that have toxicity potential [84].

Table 3. Top 20 most relevant keywords in studies related to road dust from 1906 to 2020.

\begin{tabular}{ccc}
\hline S/No & Keywords & Occurrence \\
\hline 1 & Road dust & 280 \\
2 & Street dust & 223 \\
3 & Heavy metals & 125 \\
4 & Heavy metal & 77 \\
5 & Dust & 65 \\
6 & Health risk assessment & 53 \\
7 & PM10 & 50 \\
8 & PAHs & 49 \\
9 & Health risk & 38 \\
10 & Enrichment factor & 33 \\
11 & Risk assessment & 32 \\
12 & Pollution & 30 \\
13 & Metals & 29 \\
14 & Soil & 27 \\
15 & Source apportionment & 24 \\
16 & Air pollution & 23 \\
17 & Spatial distribution & 22 \\
18 & Traffic & 21 \\
19 & ICP-MS & 20 \\
20 & Polycyclic aromatic hydrocarbons & 20 \\
\hline
\end{tabular}

The quantitative method for metal analysis is the digestion method and, thereafter, measurement using an atomic absorption spectrophotometer (AAS) [85]. In addition, many other instruments, including the inductively coupled plasma optical emission spectrophotometer (ICP-OES), which has the advantage of analyzing various metal analytes at the same time with high sensitivity, have also recently been explored. Despite the availability of these instruments and their potential, their inability to detect heavy metals at extremely low concentration limits and the isotope composition of elements is a major drawback of these instruments [56]. To overcome the drawbacks inherent in AAS and ICP-OES, the inductively coupled plasma mass spectrophotometer (ICP-MS) is currently being explored. This instrument has demonstrated the capability to detect and quantify elements with extremely low concentrations [86]. This may explain the occurrence of "ICP MS" $(n=19)$ in the top twenty list of keywords found in this study.

To comprehend the evolution of research on road dust over time, the different keywords during different time intervals were evaluated in the ranges of 1906-2005, 2006-2012, 2013-2016, 2017-2019, and 2020-2020 (Figure 4). It was observed that before 2005, research on road dust was mainly focused on air pollution and dust generally. ICP-MS, PM10, PAHs also dominated this period. Between 2006 and 2012, the research focus was limited to dust from roadsides as inferred from the dominance of keywords such as street dust, road dust, PM10, ICP-MS, trace element, air pollution, metals, and sources. In addition, from 2013 to 2016, road dust and street dust, heavy metals, spatial analysis, enrichment factors, and trace elements were dominant keywords during this period. This is an indication that focus on this type of study has now been streamlined to the detection of heavy metals as a pollutant type in road dust. Moreover, analysis of the presence of heavy metals in road dust was observed during this period. Between 2017-2019 and 2020, the analysis of heavy metals in street dust became very prominent, as these keywords, as well as their source identification and spatial analysis, were observed to take the lead during these peri- 
ods. Other keywords observed during these stages include PM10, PAHs, urban pollution, optimization, and bioaccessibility.

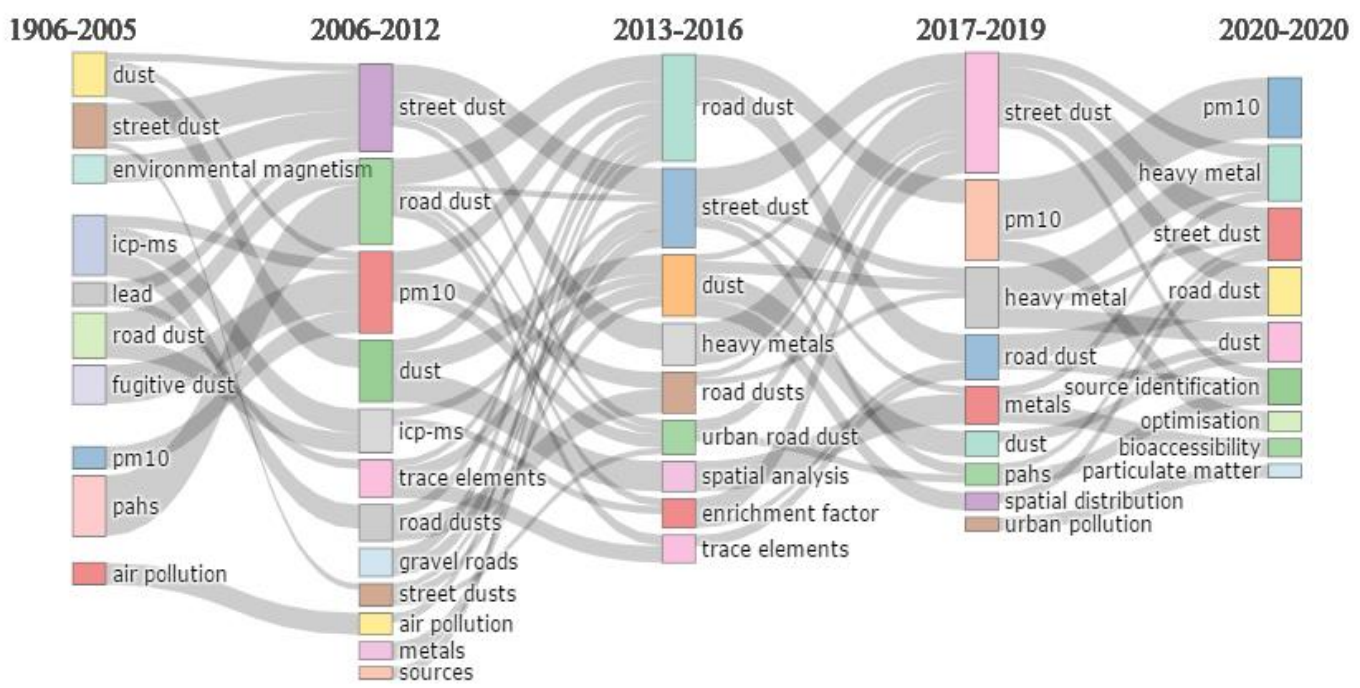

Figure 4. Thematic evolution of research on road dust during different time intervals.

\subsection{Journals' Contribution}

The diversity of journals with publications of research on road dust is an indication of the attention this research topic is gaining across different research lines. Examining the research areas of the 20 topmost journals, it can be observed that environmental science journals mostly dominated and ranked first place with 445 publications. Only two ecotoxicology journals were found (Figure 5). The 20 topmost journals accounted for threequarters of the overall publications ( $n=951,78.21 \%$ ). Science of the Total Environment with a Thomson Reuters 2020 impact factor of 7.963 ranked first place in published articles on this topic $(n=87,16.05 \%)$ followed by Atmospheric Environment with a 2020 journal impact factor of 4.798 ( $n=63,11.62 \%)$. Among the 20 topmost journals, the Journal of Hazardous Materials had the highest impact factor in 2020 with 10.588, and five other journals had an impact factor between 6.00 and 10.00, namely, Science of the Total Environment (7.963), Environmental Pollution (8.071), Chemosphere (7.086), Ecotoxicology Environment Safety (6.291), and Environment International (9.621). Careful consideration of the publishers of the journals within the 20 topmost journals revealed that Elsevier and Springer publishers reported $40 \%$ and $35 \%$ of the studies on this topic, respectively. Taylor and Francis and MDPI both published $5 \%$ of the studies in this field.

It is wort mentioning that road dust research has received enormous attention in highimpact factor, multi-disciplinary and environmental science journals devoted to publishing novel and high-quality research. The journal in which a paper is published has a significant influence on its citations. Most researchers always try as much as possible to publish in a good journal; however, it is important to highlight the article processing charges of these high-quality journals. Some institutions do not have funds that could cater to publication charges, and, hence, the researchers end up publishing their papers in non-open-access journals. Accessibility of these papers published in non-open-access journals by researchers would depend on the institutions' subscription to those journals. Papers published in openaccess journals usually receive more citations than those published in non-open-access journals, and these citations influence the impact factor of a journal. The impact factor is usually calculated every year as the ratio of papers published in a journal in the previous two years over the citations received within that period [87]. Popular sources and other trends in a research area during a certain period can be easily identified and can provide a reliable reference for researchers [88]. Furthermore, core journals provide a significant amount of information, which is helpful when searching for documents or submitting research achievements [89]. The active performance of these journals in this field can 
increase their ranking, thereby facilitating further publication of related papers in these journals in the future.

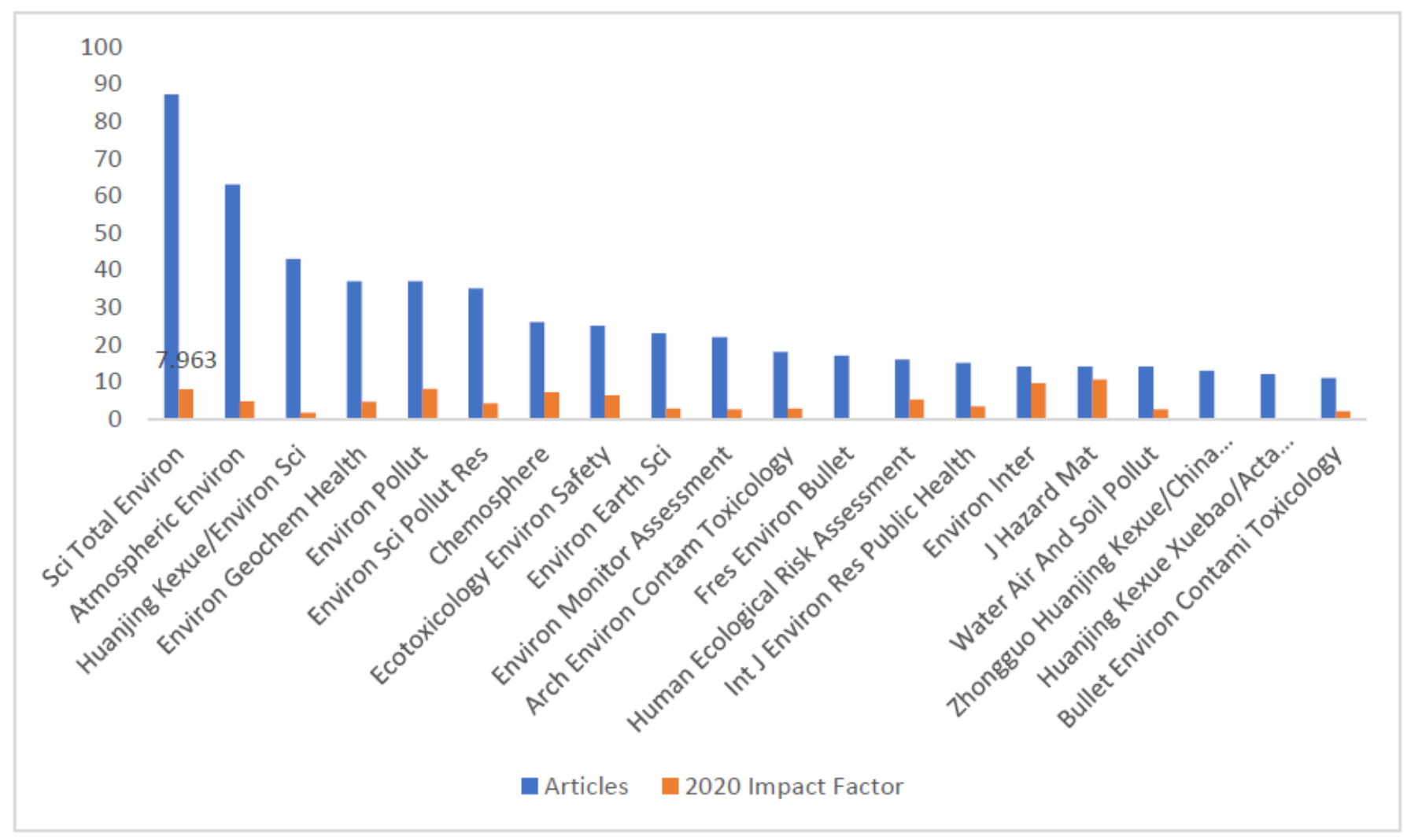

Figure 5. First 20 journals with the highest publications in studies on road dusts and their 2020 impact factors (IF) according to Thompson Reuters.

\subsection{Most Productive Authors}

This section presents the most prolific authors in terms of the number of articles published in the field of road dust pollution. Research only achieves its goal when it is shared, i.e., when an author finds an audience who values their ideas and findings. Nowadays, a reader's interest can be measured in terms of the number of views that an article receives and citations of the article. According to a report documented by Garcia et al. [90] "the validation of a research, its legitimization, and acknowledgment, depends on the reader's judgment relating to the text which can be measured by the rate and, most importantly, by its citation in other works". In the present study, Table 4 shows the first twenty most productive authors studying road dust in urban environments. The most productive author was Li X with 28 publications, followed by Li Y (24 publications), Zhang J, and Lu X, (22 publications). Other authors in the first twenty positions include Wang Y $(n=18)$, Querol X $(n=17)$, Zhang Y $(n=17)$, Keshavarzi B $(n=16)$, Yang $\mathrm{Y}$ $(n=15)$, Moore $\mathrm{F}(n=15)$, Furumai $\mathrm{H}(n=14)$, and Liu J $(n=14)$. The author citation index shows that Harrison R had the most citations, with 1486 citations, followed by Li X with 1338 citations and Amato F in third place with 1301 citations. A more significant index that must be considered is the authors' publication output over the years, as depicted in Figure S1 of Supplementary Materials. In Figure S1, the blue nodes indicate the author's productivity in a calendar year, while the threads holding the blue nodes signify consistency in the research output of each author on the subject over the years. The larger the blue nodes, the more productive an author is in a particular year. It can be observed that $\mathrm{Li} \mathrm{X}$ has been consistent over the years in the publication of research works on road dust, with more nodes held together by a thread. Larger nodes indicate a greater number of articles in a particular year. This author had the single-year highest publication output 
in 2009 and 2016. Zhang J contributed the first publication on this topic in 2006 and had the single-year highest publication in 2019. From this analysis, it was observed that Li Y was the author among the top 20 authors with the most productive articles within the survey period and with the highest single-year publication output recorded in 2017 with 13 publications. This result shows that Chinese authors dominated the ranking of the 20 topmost authors. Generally, authors from China topped the list when each author's total number of publications, h-index, and total citations were combined. The impact of an author in a particular field cannot be determined by only the number of their publications or the number of citations received; an author's level metrics such as their h-index, g-index, and m-index, are often used to obtain a more objective view of their impact [91].

Table 4. Top 20 most productive authors based on number of publications and total number of citations.

\begin{tabular}{|c|c|c|c|c|c|c|c|}
\hline Rank & Author & NP & h_Index & g_Index & m_Index & $\mathrm{TC}$ & PY_Start \\
\hline 1 & $\operatorname{LiX}$ & 28 & 12 & 28 & 0.571 & 1338 & 2001 \\
\hline 2 & Li Y & 24 & 11 & 24 & 0.846 & 787 & 2009 \\
\hline 3 & LuX & 22 & 15 & 22 & 1.154 & 1164 & 2009 \\
\hline 4 & Zhang J & 22 & 10 & 18 & 0.625 & 334 & 2006 \\
\hline 5 & Amato F & 20 & 16 & 20 & 1.231 & 1301 & 2009 \\
\hline 6 & Wang Y & 18 & 11 & 18 & 0.733 & 656 & 2007 \\
\hline 7 & Querol X & 17 & 14 & 17 & 1.077 & 1243 & 2009 \\
\hline 8 & Zhang Y & 17 & 10 & 17 & 0.909 & 551 & 2011 \\
\hline 9 & Keshavarzi B & 16 & 12 & 16 & 1.714 & 785 & 2015 \\
\hline 10 & Yang $\mathrm{Y}$ & 15 & 13 & 15 & 0.481 & 744 & 1995 \\
\hline 11 & Moore F & 15 & 11 & 15 & 1.571 & 644 & 2015 \\
\hline 12 & Furumai H & 14 & 12 & 14 & 0.667 & 408 & 2004 \\
\hline 13 & Liu J & 14 & 10 & 14 & 0.833 & 806 & 2010 \\
\hline 14 & Nakajima F & 14 & 10 & 14 & 0.556 & 316 & 2004 \\
\hline 15 & Wang L & 14 & 10 & 14 & 0.667 & 1207 & 2007 \\
\hline 16 & Alastuey A & 12 & 12 & 12 & 0.923 & 1158 & 2009 \\
\hline 17 & Egodawatta P & 12 & 9 & 12 & 0.9 & 395 & 2012 \\
\hline 18 & Harrison R & 11 & 11 & 11 & 0.239 & 1486 & 1976 \\
\hline 19 & Etyemezian V & 11 & 10 & 11 & 0.526 & 475 & 2003 \\
\hline 20 & Gillies J & 10 & 9 & 10 & 0.391 & 530 & 1999 \\
\hline
\end{tabular}

The h-index, as an indicator for assessing the quality of scientific output, is commonly used to calculate both the productivity and citation impact per author or group of authors belonging to an institute or country [92]. The h-index is an accurate reflection of the academic contribution and achievement and is applied in many bibliometric analyses [93]. However, the h-index is not suitable for comparing interdisciplinary fields [94]. This is a reflection of the high amount and quality of work on this subject from China. This also shows that scientists in China have conducted an immense amount of studies on road dust. Conversely, no authors from the countries of the Arabian Peninsula and Africa were found in the top 20 most productive authors on research in this subject, and this is probably a reflection of the difference between the level of understanding of researchers from China and that of those from other parts of the word regarding the dangers posed by the impact of road dust pollution on the environment by researchers.

\subsection{Most Cited Documents}

Citations are generally employed as performance monitors/indicators in research and within the research environment [95]. Occasionally, they are considered as good indicators of the quality and impact of research [95]. The influence of a scientific publication on research is a reflection of the number of citations generated by that publication [96]. On the other hand, the amount of citations of a published paper can also bring about constructive criticism of the study. Moreover, there is a bias in some quarters for publication citations because many argue that citation is a function of time and accessibility to literature [97]. 
In this study, the top 20 most cited documents on road dust research are presented in Table 4 . The global citation refers to the total number of citations a document received from other documents within and out of the same collection, while the global total citation per year is the total number of citations the documents received divided by the number of citable years. The extent to which a document is cited by others reflects its influence on the research landscape in a given field. Certain documents may serve as a source of a meaningful methodology, excellent background, and useful discussions for other researchers [98]. The most cited article on this subject placed first and the least cited placed last. The report of "Li XD, 2001" received the highest citation, with 738 citations and 35 citations per year. Publications reported by "Rogge WF 1993" and "FerreiraBaptista L 2005" with 600 and 599 citations are ranked second and third, respectively. The most citation gathered by the report of "Li XD, 2001" could be due to the critical discussion of heavy metal contamination in road dust, urban soils, and agricultural soils in Hong Kong. Moreover, the type of dust and soil samples as well as the environmental matrices considered for discussion in this study and the variety of parameters, including a discussion of the concentrations, levels, potential ecological implication, sample collection, and analytical techniques for heavy metal determination, may be responsible for the huge number of citations accrued by this publication. Environmental-related journals were observed to have reported $90 \%$ of the top 20 most cited publications, while only 10 journals published all of the articles within the top 20 most cited publications. This reflects authors preference of journal type. Although publications before the 20th century accrued citations over time, the publications from the 20th century dominated the top 20 most cited studies (See Table 5).

Table 5. Top 20 publications with most citations in road dust research from 1906 to 2020.

\begin{tabular}{|c|c|c|c|c|c|}
\hline $\begin{array}{l}\text { First Author and } \\
\text { Publication Year }\end{array}$ & Journal & DOI & Total Citations & TC per Year & Normalized TC \\
\hline Li XD, 2001 & Appl Geochem & 10.1016/S0883-2927(01)00045-2 & 738 & 35.1429 & 5.2217 \\
\hline Rogge WF, 1993 & Environ Sci Technol & $10.1021 / \mathrm{es} 00046 \mathrm{a} 019$ & 600 & 20.6897 & 3.5191 \\
\hline Ferreira-Baptista L, 2005 & Atmos Environ & 10.1016/j.atmosenv.2005.03.026 & 599 & 35.2353 & 8.1312 \\
\hline Harrison RM, 1981 & Environ Sci Technol & $10.1021 / \mathrm{es} 00093 \mathrm{a} 013$ & 493 & 12.0244 & 2.9819 \\
\hline Zheng N, 2010 & Sci Total Environ & 10.1016/j.scitotenv.2009.10.075 & 480 & 40 & 9.3471 \\
\hline Demiguel E, 1997 & Atmos Environ & $10.1016 / S 1352-2310(97) 00101-5$ & 413 & 16.52 & 7.8609 \\
\hline Charlesworth S, 2003 & Environ Int & $10.1016 / S 0160-4120(03) 00015-1$ & 364 & 19.1579 & 4.8944 \\
\hline Amato F, 2009 & Atmos Environ & 10.1016/j.atmosenv.2009.02.039 & 358 & 27.5385 & 5.5251 \\
\hline Banerjee ADK, 2003 & Environ Pollut & 10.1016/S0269-7491(02)00337-8 & 340 & 17.8947 & 4.5717 \\
\hline Lu XW, 2009 & J Hazard Mater & 10.1016/j.jhazmat.2008.04.052 & 310 & 23.8462 & 4.7843 \\
\hline Christoforidis A, 2009 & Geoderma & 10.1016/j.geoderma.2009.04.016 & 308 & 23.6923 & 4.7534 \\
\hline Lu XW, 2010 & J Hazard Mater & 10.1016/j.jhazmat.2009.09.001 & 304 & 25.3333 & 5.9198 \\
\hline Fergusson JE, 1991 & Sci Total Environ & 10.1016/0048-9697(91)90376-P & 290 & 9.3548 & 2.5062 \\
\hline Sezgin N, 2004 & Environ Int & $10.1016 / S 0160-4120(03) 00075-8$ & 289 & 16.0556 & 3.6182 \\
\hline Amato F, 2009 & Atmos Environ- $A$ & 10.1016/j.atmosenv.2008.12.009 & 277 & 21.3077 & 4.275 \\
\hline Duong TTT, 2011 & J Environ Manage & 10.1016/j.jenvman.2010.09.010 & 276 & 25.0909 & 6.1695 \\
\hline Fergusson JE, 1991 & Sci Total Environ & 10.1016/0048-9697(91)90376-P & 270 & 8.7097 & 2.3333 \\
\hline Apeagyei E, 2011 & Atmos Environ & 10.1016/j.atmosenv.2010.11.015 & 262 & 23.8182 & 5.8566 \\
\hline Saeedi M, 2012 & J Hazard Mater & 10.1016/j.jhazmat.2012.04.047 & 256 & 25.6 & 7.0177 \\
\hline Gietl JK, 2010 & Atmos Environ & 10.1016/j.atmosenv.2009.10.016 & 247 & 20.5833 & 4.8099 \\
\hline
\end{tabular}

\subsection{Implications of Road Dust Research on Micro-Organisms and Environmental Health}

This present study shows that other than heavy metals, PAHs have been increasingly reported in street dust, and other contaminant types of biological origin, including microorganisms, have been scarcely reported. Furthermore, the effect of road dust on microbial organisms and vegetation is a concern and requires more attention. In addition to particle size, exposure parameters and the relative bioavailability of heavy metals in street dust are important factors that affect health risk assessment [99]. However, bibliometric data obtained on this subject from our study cannot sufficiently represent the different factors affecting health risk assessment. Deviations in these parameters may result in huge errors in our overall metrics on health risk assessment. Moreover, there is a consensus in the 
literature evaluated in this study that exposure to road dust significantly causes adverse health problems in humans, such as respiratory diseases and allergies [100].

\subsubsection{Research on Microbiology and Infectious Disease in Relation to Road Dust}

Research examining the relationship between microbiology and infectious diseases and road dust remains in its infancy. Few works related to microbiological endeavors in road dust research include the bioremediation of heavy metals in urban road dust using Shewanella oneidensis [101]; microbial biodegradation of road dust suppressant acetate in the assessment of its ecotoxicological safety; and microbial compositional assessment of road dust, which revealed pathogens such as Bacillus subtilis spores, wood-rotten fungi, and other biological aerosols [102]. Moreover, Woinska and Godlewska-zylkiewicz [103] achieved separation of platinum and palladium from road dust on immobilized fungi (Aspergillus niger and Saccharomyces cerevisiae), while Godlewska-zylkiewicz and Kozlowska [104] reported solid-state recovery of palladium in road dust using immobilized Saccharomyces cerevisiae. Ram et al. [105] reported that elemental constituents in road dust adversely affect phylloplane microflora in Polyalthia longifolia, and this might have strong implications for plants and overall productivity. In addition, the report observed the absence of fungal phylloplane microflora, probably due to the presence of toxic elements, including As and $\mathrm{Hg}$, in road dust deposited on leaf surfaces [105].

Meanwhile, road dust, similar to most environmental niches, is rich in microbial diversity, but the role of road dust in the spread and epidemiology of microbial infections and related diseases is an invaluable topic that has not been well explored. Different pathogens have been isolated from house dust, including Streptococcus pneumoniae, Bacillus licheniformis, and Neisseria meningitides [106,107]. Similarly, various microbial compounds, such as bacterial 3-hydroxy fatty acids, muramic acid (MuA), endotoxin/lipopolysaccharide (LPS), fungal ergosterol, and both culturable and non-culturable microbes, have been detected in road dust [108]. Thus, it can be suggested that road dust is a potential reservoir of pathogenic microbes in the environment deserving extensive investigation, and this is a subject currently being pursued by our research group.

\subsubsection{Adverse Effects of Road Dust on Vegetation}

Vegetation improves the quality of air by absorbing carbon dioxide and emitting oxygen. The vegetation acts as a sound barricade and is important for scenic beauty and safety [109]. Roadside vegetation is the key recipient of road dust deposits, as it act as the first line of defense against urban dust pollution [110,111]. Exposure to road dust has detrimental effects on human health $[100,112]$ and vegetation $[111,113]$. Dust particles cover the leaves and block stomatal opening, which consequently prevents gas exchange and water in the atmosphere $[114,115]$. Trees growing along the roadsides have been reported to exhibit several morphological, biochemical, and anatomical changes because of higher concentrations of dust pollutants [111]. However, some trees have been reported to tolerate higher concentrations by modulating their physiological and biochemical traits. In addition, sunlight required for photosynthesis is unable to reach the leaf, and this affects normal physiological and biochemical processes of the plant, such as chlorophyll degradation, which can lead to necrosis and inhibit growth [116]. The adverse effects of heavy metal content in dust particles on vegetation have also been reported in the literature [117]. However, the dust tolerance of a plant depends on several factors, such as leaf geometry, leaf phyllotaxy, leaf structure, leaf epidermal, height and canopy of trees, and cuticular features [118]. The report of Farmer [119] highlighted that dust particles increase leaf temperature by decreasing diffusive resistance, and this makes the leaves susceptible to drought. In addition, dust particles on leaves permit easy penetration of road salt, and this consequently leads to water stress in a plant [120]. Hence, optical features of leaves, particularly the surface reflectance in the visible and shortwave infrared radiation range, are altered due to surface dust deposits [121]. Unfortunately, most of the studies on road dust have only focused on its adverse effects on humans and the ecosystem, and 
there remains a scarcity of information about the beneficial effects of chemical constituents in dust particles on the soil and vegetation.

Most researchers in this field have focused on the adverse effects of road dust deposits. However, few studies have revealed that atmospheric deposits have a great influence on the nutritional status of the ecosystem [122,123]. As a result, some of these elements have been studied in this regard; however, $\mathrm{N}$ and $\mathrm{P}$ have received special attention because of their significant impact on plant growth [124]. The amount of nutrients released from the atmospheric deposit to the ecosystem depends on the capacity of the plant nutrient uptake and soil nutrient contents, among other factors. Furthermore, Kome et al. [125] emphasized in their report that clay can improve the nutrient- and water-holding capacity of soils and increase their fertility, and this is in accordance with the findings of Newman [126], who emphasized that the nutrients in dust deposits can enrich soils with low nutrient contents and improve soil fertility with a significant increase in vegetation productivity. Furthermore, granites used in road construction contain some important chemical substances that can enrich soils and improve the growth of roadside vegetation when released through dust particles to the environment. Nevertheless, there is a dearth of studies in the area of examining the beneficial effects in terms of nutrition that the chemical substances in road dust deposits may have on the roadside vegetation and soil, and, hence, researchers in this field are encouraged to explore this topic in their future studies.

\subsubsection{Study Limitations}

Since this study employed and relied on published information from databases in the scientific domain and analyses of data processed using the bibliometric framework, limitations could not be avoided. Two databases (WoS and Scopus), as well as only papers published in English, were employed in this study, and, therefore, future studies should consider including other databases and non-English language publications to accommodate other articles that might greatly influence the bibliometric results of this subject matter. Despite such limitations, this study will aid researchers intending to identify hotspots and areas in need of research in this field as well as those with the aim of determining influential papers and authors in this research niche.

\section{Conclusions and Future Prospects}

The present study provides an overview and describes the trend of scientific research output on road dust from 1906 to 2020. The bibliometric analysis was comprehensive and relatively objective based on the data retrieved from the two databases used in the study. Our findings revealed a significant growth in the research output over the years, and research interest in the subject was noted to have risen drastically as compared when this research subject was in its infancy. Interestingly, road dust research has received enormous consideration in some high-quality scientific domains, and we noted that there was a strong single-country publication tendency among researchers as compared to multiplecountries publications. Similarly, it was observed that Japanese and Chinese institutions and academics dominated research in this field, and the two prominent leading countries were China and the United Kingdom. The engagement of researchers from these world leaders in this field has been directed toward the common goal of solving environmental issues caused by road dust deposits, focusing especially on their adverse effects on public health and the ecosystem. Literature data retrieved from this study suggest that heavy traffic urban regions are more exposed to contamination from road dust. Moreover, major studies on this subject have been carried out in developed nations, and only a few have been published in low-income countries. Countries located in the Arabian Peninsula and Africa have barely contributed to the research field of road dust, despite the fact that this research topic should be of priority considering the peculiarity of their geography and climate. We are optimistic that this report will be a good impetus to encourage interest in road dust research, setting up new sites, and enlarging the framework of research in these regions in the future. 
Our findings suggest that future research should also focus on determining the levels and fate of contaminants, such as hydrocarbons and microbial diversities, in road dust, even in countries that have extensively studied this subject and those that have seldom reported research in this field. Furthermore, most countries do not have standard regulations for heavy metal and other contaminants limits in road dust, as most researchers have only compared results from this subject with heavy metal concentrations in soil and sediments from areas other than road or street dust. Therefore, this calls for concerted efforts and a greater amount of research to arrive at the acceptable limits for contaminants in road dust. Future research should promote partnerships and employ real-life results to generate a comprehensive database on the permissible level of heavy metals and other contaminants in road dust. This will not only enhance science and community engagement and communication but will certainly improve public awareness of the burdens of road dust.

Although over the years, the focus of researchers has been on the adverse effects of heavy metals and related substances in road dust on humans, animals, and vegetation, no single study has reported on the nutritional benefits of chemical substances, such as nitrogen $(\mathrm{N})$, phosphorus (P), and total organic carbon (TOC), in road dust deposited near vegetation and soil. Therefore, these researchers in the field should actively focus on this topic in the future. Similarly, research regarding the relationship between microbiological and infectious diseases and road dust is still in its infancy, but evidence suggests that road dust is rich in pathogenic microorganisms, such as bacteria, spores, protozoa, fungi, and viruses. This study revealed that there remains a lack of research attention given to the role of road dust-borne pathogens. The role of road dust in the spread and epidemiology of microbial infections and related diseases is an invaluable topic that needs to be explored for sustainable public health in relation to respiratory infections and diseases. Moreover, this study suggests cleaner and sustainable practices, such as the collection and recycling of road dust for construction purposes and extractive recovery of road-dust-associated metals.

Supplementary Materials: The following are available online at https: / www.mdpi.com/article/ 10.3390/su132011516/s1, Figure S1: Top authors' publication output on road dust research over the years.

Author Contributions: Conceptualization, L.S. and A.I.O.; methodology, T.C.E.; software, T.C.E.; validation, M.O.O., K.O. and A.I.; formal analysis, T.C.E.; investigation, M.O.O., K.O., T.C.E. and A.I.; resources, L.S. and A.I.O.; data curation, T.C.E.; writing-original draft preparation, M.O.O., K.O., T.C.E., A.I.; writing—review and editing, L.S., A.I.O.; supervision, L.S. and A.I.O.; funding acquisition, L.S. and A.I.O. All authors have read and agreed to the published version of the manuscript.

Funding: This research was funded by University of Sharjah, grant number 1901050643.

Acknowledgments: The University of Sharjah is appreciated for funding this research study.

Conflicts of Interest: The authors declare no conflict of interest.

\section{References}

1. Bhardwaj, A.; Aggarwal, R.K.; Bhardwaj, S.K. A Review on Impacts of Road Activities and Vehicular Emissions on Native Ecosystems in Mountainous Region. Curr. World Environ. 2017, 14, 194. [CrossRef]

2. Organization for Economic Cooperation and Development. Road Transport Demand: Meeting the Challenge; OECD: Paris, France, 2002; pp. 1-195.

3. Manisalidis, I.; Stavropoulou, E.; Stavropoulos, A.; Bezirtzoglou, E. Environmental and health impacts of air pollution: A review. Front. Public Health 2020, 8, 14. [CrossRef] [PubMed]

4. Hatami, Z.; Rezvani Moghaddam, P.; Rashki, A.; Nasiri Mahallati, M.; Habibi Khaniani, B. Effects of desert dust on yield and yield compo-nents of cowpea (Vigna unguiculata L.). Arch. Agron. Soil Sci. 2018, 64, 1446-1458. [CrossRef]

5. Swami, A. Impact of automobile induced air pollution on road side vegetation: A review. Essence Int. J. Environ. Rehab. Conserv. 2018, 9, 101-116. [CrossRef]

6. Samoli, E.; Kougea, E.; Kassomenos, P.; Analitis, A.; Katsouyanni, K. Does the presence of desert dust modify the effect of PM10 on mortality in Athens, Greece? Sci. Total Environ. 2011, 409, 2049-2054. [CrossRef] [PubMed]

7. Shi, G.; Chen, Z.; Bi, C.; Li, Y.; Teng, J.; Wang, L.; Xu, S. Comprehensive assessment of toxic metals in urban and suburban street deposited sediments (SDSs) in the biggest metropolitan area of China. Environ. Pollut. 2010, 158, 694-703. [CrossRef] 
8. Noh, H.J.; Lee, S.K.; Yu, J.H. Identifying effective fugitive dust control measures for construction projects in Korea. Sustainability 2018, 10, 1206. [CrossRef]

9. Sager, M. Urban Soils and Road Dust-Civilization Effects and Metal Pollution-A Review. Environments 2020, 7, 98. [CrossRef]

10. Greening, T. Quantifying the Impacts of Vehicle-Generated Dust: A Comprehensive Approach; DFID Report; World Bank: Washington, DC, USA, 2011; pp. 1-84.

11. Munsif, R.; Zubair, M.; Aziz, A.; Zafar, M.N. Industrial Air Emission Pollution: Potential Sources and Sustainable Mitigation. In Environmental Emissions; IntechOpen: London, UK, 2021.

12. Hou, S.; Zheng, N.; Tang, L.; Ji, X.; Li, Y.; Hua, X. Pollution characteristics, sources, and health risk assessment of human exposure to $\mathrm{Cu}, \mathrm{Zn}, \mathrm{Cd}$ and $\mathrm{Pb}$ pollution in urban street dust across China between 2009 and 2018. Environ. Int. 2019, 128, $430-437$. [CrossRef]

13. Pan, H.; Lu, X.; Lei, K. A comprehensive analysis of heavy metals in urban road dust of Xi'an, China: Contamination, source apportionment and spatial distribution. Sci. Total Environ. 2017, 609, 1361-1369. [CrossRef]

14. Zgłobicki, W.; Telecka, M.; Skupiński, S. Assessment of short-term changes in street dust pollution with heavy metals in Lublin (E Poland)-levels, sources and risks. Environ. Sci. Pollut. Res. 2019, 26, 35049-35060. [CrossRef]

15. Wei, X.; Gao, B.; Wang, P.; Zhou, H.; Lu, J. Pollution characteristics and health risk assessment of heavy metals in street dusts from different functional areas in Beijing, China. Ecotoxicol. Environ. Saf. 2015, 112, 186-192. [CrossRef] [PubMed]

16. Trujillo-González, J.M.; Torres-Mora, M.A.; Keesstra, S.; Brevik, E.C.; Jiménez-Ballesta, R. Heavy metal accumulation related to population density in road dust samples taken from urban sites under different land uses. Sci. Total Environ. 2016, 553, 636-642. [CrossRef] [PubMed]

17. Kumar, M.; Furumai, H.; Kurisu, F.; Kasuga, I. Tracing source and distribution of heavy metals in road dust, soil and soakaway sediment through speciation and isotopic fingerprinting. Geoderma 2013, 211-212, 8-17. [CrossRef]

18. Shi, D.; Lu, X. Accumulation degree and source apportionment of trace metals in smaller than $63 \mu \mathrm{m}$ road dust from the areas with different land uses: A case study of Xi'an, China. Sci. Total Environ. 2018, 636, 1211-1218. [CrossRef]

19. Urrutia-Goyes, R.; Hernandez, N.; Carrillo-Gamboa, O.; Nigam, K.; Ornelas-Soto, N. Street dust from a heavily-populated and industrialized city: Evaluation of spatial distribution, origins, pollution, ecological risks and human health repercussions. Ecotoxicol. Environ. Saf. 2018, 159, 198-204. [CrossRef]

20. Cai, K.; Li, C. Street dust heavy metal pollution source apportionment and sustainable management in a typical city—shijiazhuang, china. Int. J. Environ. Res. Public Health 2019, 16, 2625. [CrossRef]

21. Wei, B.; Yang, L. A review of heavy metal contaminations in urban soils, urban road dusts and agricultural soils from China. Microchem. J. 2010, 94, 99-107. [CrossRef]

22. Jiang, Y.; Shi, L.; Guang, A.-L.; Mu, Z.; Zhan, H.; Wu, Y. Contamination levels and human health risk assessment of toxic heavy metals in street dust in an industrial city in Northwest China. Environ. Geochem. Health 2018, 40, 2007-2020. [CrossRef]

23. Lu, X.; Wang, L.; Li, L.Y.; Lei, K.; Huang, L.; Kang, D. Multivariate statistical analysis of heavy metals in street dust of Baoji, NW China. J. Hazard. Mater. 2010, 173, 744-749. [CrossRef]

24. Mohmand, J.; Eqani, S.A.M.A.S.; Fasola, M.; Alamdar, A.; Mustafa, I.; Ali, N.; Liu, L.; Peng, S.; Shen, H. Human exposure to toxic metals via contaminated dust: Bio-accumulation trends and their potential risk estimation. Chemosphere 2015, 132, 142-151. [CrossRef] [PubMed]

25. Yongming, H.; Peixuan, D.; Junji, C.; Posmentier, E.S. Multivariate analysis of heavy metal contamination in urban dusts of Xi'an, Central China. Sci. Total Environ. 2006, 355, 176-186. [CrossRef]

26. Lu, X.; Wang, L.; Lei, K.; Huang, J.; Zhai, Y. Contamination assessment of copper, lead, zinc, manganese and nickel in street dust of Baoji, NW China. J. Hazard. Mater. 2009, 161, 1058-1062. [CrossRef] [PubMed]

27. Zhang, M.; Wang, H. Concentrations and chemical forms of potentially toxic metals in road-deposited sediments from different zones of Hangzhou, China. J. Environ. Sci. 2009, 21, 625-631. [CrossRef]

28. Saeedi, M.; Li, L.Y.; Salmanzadeh, M. Heavy metals and polycyclic aromatic hydrocarbons: Pollution and ecological risk assessment in street dust of Tehran. J. Hazard. Mater. 2012, 227-228, 9-17. [CrossRef]

29. Acosta, J.; Gabarron, M.; Faz, A.; Martínez-Martínez, S.; Zornoza, R.; Arocena, J. Influence of population density on the concentration and speciation of metals in the soil and street dust from urban areas. Chemosphere 2015, 134, 328-337. [CrossRef]

30. Gope, M.; Masto, R.E.; George, J.; Hoque, R.R.; Balachandran, S. Bioavailability and health risk of some potentially toxic elements $(\mathrm{Cd}, \mathrm{Cu}, \mathrm{Pb}$ and $\mathrm{Zn})$ in street dust of Asansol, India. Ecotoxicol. Environ. Saf. 2017, 138, 231-241. [CrossRef] [PubMed]

31. Men, C.; Liu, R.; Xu, L.; Wang, Q.; Guo, L.; Miao, Y.; Shen, Z. Source-specific ecological risk analysis and critical source identification of heavy metals in road dust in Beijing, China. J. Hazard. Mater. 2020, 388, 121763. [CrossRef]

32. Youngblood, M.; Lahti, D. A bibliometric analysis of the interdisciplinary field of cultural evolution. Palgrave Commun. 2018, 4, 1-9.

33. Ellegaard, O.; Wallin, J.A. The bibliometric analysis of scholarly production: How great is the impact? Scientometrics 2015, 105, 1809-1831. [CrossRef]

34. Moral-Muñoz, J.A.; Herrera-Viedma, E.; Santisteban-Espejo, A.; Cobo, M.J. Software tools for conducting bibliometric analysis in science: An up-to-date review. Prof. Inform. 2020, 29, e290103. [CrossRef]

35. Skute, I.; Zalewska-Kurek, K.; Hatak, I.; De-Weerd-Nederhof, P. Mapping the field: A bibliometric analysis of the literature on university-industry collaborations. J. Technol. Transf. 2019, 44, 916-947. [CrossRef] 
36. Sweileh, W.M. Bibliometric analysis of peer-reviewed literature on climate change and human health with an emphasis on infectious diseases. Glob. Health 2020, 16, 1-17. [CrossRef]

37. Romero, L.; Portillo-Salido, E. Trends in sigma-1 receptor research: A 25-year bibliometric analysis. Front. Pharmacol. 2019, 10, 564. [CrossRef] [PubMed]

38. Dhital, S.; Rupakheti, D. Bibliometric analysis of global research on air pollution and human health: 1998-2017. Environ. Sci. Pollut. Res. 2019, 26, 13103-13114. [CrossRef]

39. Li, Y.; Wang, Y.; Rui, X.; Li, Y.; Li, Y.; Wang, H.; Zuo, J.; Tong, Y. Sources of atmospheric pollution: A bibliometric analysis. Scientometrics 2017, 112, 1025-1045. [CrossRef]

40. Qin, F.; Du, J.; Gao, J.; Liu, G.; Song, Y.; Yang, A.; Wang, H.; Ding, Y.; Wang, Q. Bibliometric Profile of Global Microplastics Research from 2004 to 2019. Int. J. Environ. Res. Public Health 2020, 17, 5639. [CrossRef]

41. Liu, Z.; Yang, J.; Zhang, J.; Xiang, H.; Wei, H. A Bibliometric Analysis of Research on Acid Rain. Sustainability 2019, $11,3077$. [CrossRef]

42. Castor, K.; Mota, F.B.; da Silva, R.M.; Cabral, B.P.; Maciel, E.L.; de Almeida, I.N.; Arakaki-Sanchez, D.; Andrade, K.B.; Testov, V.; Vasilyeva, I.; et al. Mapping the tuberculosis scientific landscape among BRICS countries: A bibliometric and network analysis. Mem. Inst. Oswaldo Cruz. 2020, 115, e190342. [CrossRef]

43. Dong, R.; Wang, H.; Ye, J.; Wang, M.; Bi, Y. Publication trends for Alzheimer's disease worldwide and in China: A 30-year bibliometric analysis. Front. Hum. Neurosci. 2019, 13, 259. [CrossRef]

44. Gray Neils, M.E.; Pfaeffle, H.O.; Kulatti, A.T.; Titova, A.; Lyles, G.S.; Plotnikova, Y.; Zorkaltseva, E.; Ogarkov, O.B.; Vitko, S.M.; Dillingham, R.A.; et al. A Geospatial Bibliometric Review of the HIV / AIDS Epidemic in the Russian Federation. Front. Public Health 2020, 8, 75. [CrossRef]

45. Wambu, E.W.; Ho, Y.S. A bibliometric analysis of drinking water research in Africa. Water SA 2016, 42, 612-620. [CrossRef]

46. Dwivedi, S. Global allergy research during 1994-2013: A scientometric study. Ann. Libr. Inf. Stud. (ALIS) 2016, 63, 16-23.

47. Gao, Y.; Wang, Y.; Zhai, X.; He, Y.; Chen, R.; Zhou, J.; Li, M.; Wang, Q. Publication trends of research on diabetes mellitus and T cells (1997-2016): A 20-year bibliometric study. PLoS ONE 2017, 12, e0184869. [CrossRef] [PubMed]

48. Garrido-Cardenas, J.A.; Cebrián-Carmona, J.; González-Cerón, L.; Manzano-Agugliaro, F.; Mesa-Valle, C. Analysis of Global Research on Malaria and Plasmodium vivax. Inter. J. Environ. Res. Public Health 2019, 16, 1928. [CrossRef] [PubMed]

49. Kolle, S.R.; Shankarappa, T.H. Publication trends in food-borne disease research (1991-2015): A web of science Core collection based analysis. J. Agric. Food Inf. 2017, 18, 53-63. [CrossRef]

50. Liu, X.; Liu, N.; Zhou, M.; Lu, Y.; Li, F. Bibliometric analysis of global research on the rehabilitation of spinal cord injury in the past two decades. Ther. Clin. Risk Manag. 2019, 15, 1. [CrossRef]

51. Ekundayo, T.C.; Igwaran, A.; Oluwafemi, Y.D.; Okoh, A.I. Global bibliometric meta-analytic assessment of research trends on microbial chlorine resistance in drinking water/water treatment systems. J. Environ. Manag. 2021, 278, 111641. [CrossRef]

52. Ekundayo, T.C.; Olasehinde, T.A.; Okaiyeto, K.; Okoh, A.I. Microbial Pathogenesis and Pathophysiology of Alzheimer's Disease: A Systematic Assessment of Microorganisms' Implications in the Neurodegenerative Disease. Front. Neurosci. 2021, 15, 454. [CrossRef]

53. Ekundayo, T.C.; Okoh, A.I. A global bibliometric analysis of Plesiomonas-related research (1990-2017). PLoS ONE 2018, 13, e0207655. [CrossRef]

54. Olisah, C.; Okoh, O.O.; Okoh, A.I. Occurrence of organochlorine pesticide residues in biological and environmental matrices in Africa: A two-decade review. Heliyon 2020, 6, e03518. [CrossRef]

55. Okaiyeto, K.; Ekundayo, T.C.; Okoh, A.I. Global research trends on bioflocculant potentials in wastewater remediation from 1990 to 2019 using a bibliometric approach. Lett. Appl. Microbiol. 2020, 71, 567-579. [CrossRef]

56. Okaiyeto, K.; Oguntibeju, O.O. Trends in diabetes research outputs in South Africa over 30 years from 2010-2019: A bibliometric analysis. Saudi J. Biol. Sci. 2021, 28, 2914-2924. [CrossRef] [PubMed]

57. Ojemaye Mike, O.; Okoh Anthony, I. Global research direction on Pt and Pt based electro-catalysts for fuel cells application between 1990 and 2019: A bibliometric analysis. Int. J. Energy Res. 2021. [CrossRef]

58. Wei, B.; Jiang, F.; Li, X.; Mu, S. Contamination levels assessment of potential toxic metals in road dust deposited in different types of urban environment. Environ. Earth Sci. 2010, 61, 1187-1196. [CrossRef]

59. Gao, F.; Jia, X.; Zhao, Z.; Chen, C.C.; Xu, F.; Geng, Z.; Song, X. Bibliometric analysis on tendency and topics of artificial intelligence over last decade. Microsyst. Technol. 2019, 27, 1545-1557. [CrossRef]

60. Aghaei Chadegani, A.; Salehi, H.; Yunus, M.; Farhadi, H.; Fooladi, M.; Farhadi, M.; Ale Ebrahim, N. A comparison between two main academic literature collections: Web of science and scopus databases. Asian Soc. Sci. 2013, 9, 18-26. [CrossRef]

61. Montoya, F.G.; Alcayde, A.; Baños, R.; Manzano-Agugliaro, F. A fast method for identifying worldwide scientific collaborations using the Scopus database. Telemat. Inform. 2018, 35, 168-185. [CrossRef]

62. Zou, Y.; Luo, Y.; Zhang, J.; Xia, N.; Tan, G.; Huang, C. Bibliometric analysis of oncolytic virus research, 2000 to 2018. Medicine 2019, 98, e16817. [CrossRef]

63. Aria, M.; Cuccurullo, C. Bibliometrix: An R-tool for comprehensive science mapping analysis. J. Informetr. 2017, 11, 959-975. [CrossRef]

64. Lin, M.; Gui, H.; Wang, Y.; Peng, W. Pollution characteristics, source apportionment and health risk of heavy metals in street dust of Suzhou, China. Environ. Sci. Pollut. Res. 2017, 24, 1987-1998. [CrossRef] [PubMed] 
65. Li, Z.; Feng, X.; Li, G.; Bi, X.; Zhu, J.; Qin, H.; Dai, Z.; Liu, J.; Li, Q.; Sun, G. Distributions, sources and pollution status of 17 trace metal/metalloids in the street dust of a heavily industrialized city of central China. Environ. Pollut. 2013, 182, 408-416. [CrossRef] [PubMed]

66. Mathur, R.; Balaram, V.; Satyanarayanan, M.; Sawant, S.S. Assessment of heavy metal contamination of road dusts from industrial areas of Hyderabad, India. Environ. Monit. Assess. 2016, 188, 514. [CrossRef] [PubMed]

67. Aslam, J.; Khan, S.A.; Khan, S.H. Heavy metals contamination in roadside soil near different traffic signals in Dubai, United Arab Emirates. J. Saudi Chem. Soc. 2013, 17, 315-319. [CrossRef]

68. Shi, X.; Chen, L.; Wang, J. Multivariate analysis of heavy metal pollution in street dusts of Xianyang city, NW China. Environ. Earth Sci. 2013, 69, 1973-1979. [CrossRef]

69. Dusdal, J.; Powell, J.J. Benefits, motivations, and challenges of international collaborative research: A sociology of science case study. Sci. Public Policy 2021, 48, 235-245. [CrossRef]

70. Geaney, F.; Scutaru, C.; Kelly, C.; Glynn, R.W.; Perry, I. Type 2 Diabetes Research Yield, 1951-2012: Bibliometrics Analysis and Density-Equalizing Mapping. PLoS ONE 2015, 10, e0133009. [CrossRef] [PubMed]

71. Brüggmann, D.; Mäule, L.-S.; Klingelhöfer, D.; Schöffel, N.; Gerber, A.; Jaque, J.M.; Groneberg, D.A. World-wide architecture of osteoporosis research: Density-equalizing mapping studies and gender analysis. Climacteric 2016, 19, 463-470. [CrossRef] [PubMed]

72. Chen, X.; Xia, X.; Zhao, Y.; Zhang, P. Heavy metal concentrations in roadside soils and correlation with urban traffic in Beijing, China. J. Hazard. Mater. 2010, 181, 640-646. [CrossRef]

73. Naderizadeh, Z.; Khademi, H.; Ayoubi, S. Biomonitoring of atmospheric heavy metals pollution using dust deposited on date palm leaves in southwestern Iran. Atmósfera 2016, 29, 141-155. [CrossRef]

74. Madany, I.M.; Akhter, M.S.; Al Jowder, O.A. The correlations between heavy metals in residential indoor dust and outdoor street dust in Bahrain. Environ. Int. 1994, 20, 483-492.

75. Al-Rajhi, M.A.; Seaward, M.R.D.; Al-Aamer, A.S. Metal levels in indoor and outdoor dust in Riyadh, Saudi Arabia. Environ. Int. 1996, 22, 315-324. [CrossRef]

76. Fardi, A.; Kodonas, K.; Gogos, C. Economides N Top-cited articles in endodontic journals. J. Endod. 2011, 37, 1183-1190. [CrossRef]

77. Olisah, C.; Adams, J.B. Systematic mapping of organophosphate contaminant (OPC) research trends between 1990 and 2018 Environ. Geochem. Health 2020, 3. [CrossRef] [PubMed]

78. Parish, A.J.; Boyack, K.W.; Ioannidis, J.P. Dynamics of co-authorship and productivity across different fields of scientific research. PLoS ONE 2018, 13, e0189742. [CrossRef] [PubMed]

79. Bukvova, H. Studying Research Collaboration: A Literature Review. Sprouts Work Paper Information System. 2010, p. 10. Available online: https: / / aisel.aisnet.org/sprouts_all/326 (accessed on 10 October 2021).

80. Bozeman, B.; Fay, D.; Slade, C.P. Research collaboration in universities and academic entrepreneurship: The-state-of-the-art. J. Technol. Transf. 2012, 38, 1-67. [CrossRef]

81. Katz, J.S.; Hicks, D. How much is a collaboration worth? A calibrated bibliometric model. Scientometrics 1997, 40, 541-554. [CrossRef]

82. Puljak, L.; Vari, S.G. Significance of research networking for enhancing collaboration and research productivity. Croat. Med. J. 2014, 55, 181. [CrossRef]

83. Pei, W.; Peng, R.; Gu, Y.; Zhou, X.; Ruan, J. Research trends of acupuncture therapy on insomnia in two decades (from 1999 to 2018): A bibliometric analysis. BMC Complement. Altern. Med. 2019, 19, 225. [CrossRef]

84. Duffus, J.H. "Heavy metals"-A meaningless term? (IUPAC technical report). Pure Appl. Chem. 2002, 74, 793-807. [CrossRef]

85. Ojemaye, M.O.; Okoh, O.O.; Okoh, A.I. Study on the adsorption of metal ions onto azomethine functionalized magnetic nanoparticles in a single-and competitive-aqueous system. Desalin. Water Treat. 2019, 146, 236-244. [CrossRef]

86. Baralkiewicz, D.; Gramowska, H.; Hanc, A.; Krzyzaniak, I. A comparison of ICP-OES and ICP-MS in the determination of elements in lake water. At. Spectrosc. 2007, 28, 164-170.

87. Van Leeuwen, T.N.; Wouters, P.F. Analysis of publications on journal impact factor over time. Front. Res. Metr. Anal. 2017, 2, 4. [CrossRef]

88. Zhuang, Y.; Jiang, N.; Wu, Z.; Li, Q.; Chiu, D.K.W.; Hu, H. Efficient and robust large medical image retrieval in mobile cloud computing environment. Inf. Sci. 2014, 263, 60-86. [CrossRef]

89. Wang, X.; Guo, J.; Gu, D.; Yang, Y.; Yang, X.; Zhu, K. Tracking knowledge evolution, hotspots and future directions of emerging technologies in cancers research: A bibliometrics review. J. Cancer 2019, 10, 2643-2653. [CrossRef]

90. Garcia, D.C.F.; Gattaz, C.C.; Gattaz, N.C. The relevance of title, abstract and keywords for scientific paper writing. Rev. Adm. Contemp. 2019, 23, 1-18. [CrossRef]

91. Bornmann, L.; Daniel, H.D. What do we know about the h index? J. Am. Soc. Inf. Sci.Technol. 2007, 58, 1381-1385. [CrossRef]

92. Jones, T.; Huggett, S.; Kamalski, J. Finding a way through the scientific literature: Indexes and measures. World Neurosurg. 2011, 76, 36-38. [CrossRef]

93. Miao, Y.; Zhang, Y.; Yin, L.H. Trends in hepatocellular carcinoma research from 2008 to 2017: A bibliometric analysis. PeerJ 2018, 6, e5477. [CrossRef]

94. Guilak, F.; Jacobs, C.R. The H-index: Use and overuse. J. Biomech. 2011, 44, 208-209. [CrossRef] 
95. Aksnes, D.W.; Langfeldt, L.; Wouters, P. Citations, Citation Indicators, and Research Quality: An Overview of Basic Concepts and Theories. SAGE Open 2019, 9, 1-17. [CrossRef]

96. Van Noorden, R.; Maher, B.; Nuzzo, R. The top 100 papers. Nature 2014, 514, 550-553. [CrossRef]

97. Cheek, J.; Garnham, B.; Quan, J. What's in a number? Issues in providing evidence of impact and quality of research(ers). Qual. Health Res. 2006, 16, 423-435. [CrossRef]

98. Cooper, I.D. Bibliometrics basics. J. Med Libr. Assoc. JMLA 2015, 103, 217. [CrossRef]

99. Tian, S.; Liang, T.; Li, K. Fine road dust contamination in a mining area presents a likely air pollution hotspot and threat to human health. Environ. Int. 2019, 128, 201-209. [CrossRef] [PubMed]

100. Adamiec, E.; Jarosz-Krzemińska, E. Human Health Risk Assessment associated with contaminants in the finest fraction of sidewalk dust collected in proximity to trafficked roads. Sci. Rep. 2019, 9, 16364. [CrossRef] [PubMed]

101. Achal, V.; Mukerjee, A.; Reddy, M.S. Biogenic treatment improves the durability and remediates the cracks of concrete structures. Constr. Build. Mater. 2013, 48, 1-5. [CrossRef]

102. Škrbić, B.; Milovac, S.; Matavulj, M. Multielement profiles of soil, road dust, tree bark and wood-rotten fungi collected at various distances from high-frequency road in urban area. Ecol. Indic. 2012, 13, 168-177. [CrossRef]

103. Woińska, S.; Godlewska-Żyłkiewicz, B. Determination of platinum and palladium in road dust after their separation on immobilized fungus by electrothermal atomic absorption spectrometry. Spectrochim. Acta Part B At. Spectr. 2011, 66, 522-528. [CrossRef]

104. Godlewska-Żyłkiewicz, B.; Kozłowska, M. Solid phase extraction using immobilized yeast Saccharomyces cerevisiae for determination of palladium in road dust. Anal. Chim. Acta 2005, 539, 61-67. [CrossRef]

105. Ram, J.; Corkindale, D.; Wu, M.-L. Examining the role of system quality in ERP projects. Ind. Manag. Data Syst. 2013, 113, 350-366. [CrossRef]

106. Jusot, J.F.; Neill, D.R.; Waters, E.M.; Bangert, M.; Collins, M.; Moreno, L.B.; Lawan, K.G.; Moussa, M.M.; Dearing, E.; Everett, D.B.; et al. Airborne dust and high temperatures are risk factors for invasive bacterial disease. J. Allergy Clin. Immunol. 2017, 139, 977-986. [CrossRef] [PubMed]

107. Pickering, J.; Teo, T.H.; Thornton, R.B.; Kirkham, L.A.; Zosky, G.R.; Clifford, H.D. Bacillus licheniformis in geogenic dust induces inflammation in respiratory epithelium. Environ. Res. 2018, 164, 248-254. [CrossRef] [PubMed]

108. Zhao, Z.; Sebastian, A.; Larsson, L.; Wang, Z.; Zhang, Z.; Norbäck, D. Asthmatic symptoms among pupils in relation to microbial dust exposure in schools in Taiyuan, China. Pediatr. Allergy Immunol. 2008, 19, 455-465. [CrossRef] [PubMed]

109. Sahu, C.; Sahu, S.K. Air pollution tolerance index (APTI), anticipated performance index (API), carbon sequestration and dust collection potential of Indian tree species-A review. Int. J. Emerg. Res. Manag. Technol. 2015, 4, 37-40.

110. Dong, X.; Yang, W.; Ulgaiti, S.; Yan, M.; Zhang, X. The impact of human activities on natural capital and ecosystem services of natural pastures in North Xinjiang, China. Ecol. Model. 2012, 225, 28-39. [CrossRef]

111. Singh, H.; Yadav, M.; Kumar, N.; Kumar, A.; Kumar, M. Assessing adaptation and mitigation potential of roadside trees under the influence of vehicular emissions: A case study of Grevillea robusta and Mangifera indica planted in an urban city of India. PLoS ONE 2020, 15, e0227380. [CrossRef]

112. Khan, R.K.; Strand, M.A. Road dust and its effect on human health: A literature review. Epidem. Health 2018, 40 , e2018013. [CrossRef]

113. Manoochehri, K.; Shirvany, A.; Attarod, P.; Khodakarami, Y. Dust filtration ability of Fraxinus rotundifolia, Platanus orientalis, and Robinia pseudoacacia trees in Kermanshah, West of Iran. Iranian J. Forest 2016, 8, 1-10. (In Persian)

114. Achakzai, K.; Khalid, S.; Adrees, M.; Bibi, A.; Ali, S.; Nawaz, R.; Rizwan, M. Air pollution toler-ance index of plants around brick kilns in Rawalpindi. Pakistan. J. Environ. Manag. 2017, 190, 252-258. [CrossRef]

115. Javanmard, Z.; Kouchaksaraei, M.; Bahrami, H.A.; Hosseini, S.M.; Modares Sanavi, S.A.M. Effects of dust on morpho-physiological response of Fraxinus rotundifolia Mill. Seedling. Iran. J. Forest 2019, 11, 309-323.

116. Chaturvedi, R.K.; Prasad, S.; Rana, S.; Obaidullah, S.M.; Pandey, V.; Singh, H. Effect of dust load on the leaf attributes of the tree species growing along the roadside. Environ. Monit. Assess. 2013, 185, 383-391. [CrossRef] [PubMed]

117. Jyothi, S.J.; Jaya, D.S. Evaluation of air pollution tolerance index of selected plant species along roadsides in Thiruvananthapuram, Kerala. J. Environ. Biol. 2010, 31, 379-386. [PubMed]

118. Prusty, B.A.K.; Mishra, P.C.; Azeez, P.A. Dust accumulation and leaf pigment content in vegetation near the national highway at Sam-balpur, Orissa, India. Ecotoxicol. Environ. Saf. 2005, 60, 228-235. [CrossRef]

119. Farmer, A.M. The effects of dust on vegetation-A review. Environ. Pollut. 1993, 79, 63-75. [CrossRef]

120. Fluckiger, W.; Braun, S.; Fluckiger-Keller, H. Effect of the interaction between road salt and road dust upon water relations of young trees. In Seaward Urban Ecology; Bornkamm, R., Lee, J.A., Seaward, M.R.D., Eds.; Blackwell Scientific Publications: Oxford, UK, 1982; pp. 331-332.

121. Keller, J.; Lamprecht, R. Road dust as an indicator for air pollution transport and deposition: An application of SPOT imagery. Remote Sens. Environ. 1995, 54, 1-12. [CrossRef]

122. Lepori, F.; Keck, F. Effects of atmospheric nitrogen deposition on remote freshwater ecosystems. Ambio 2012, 41, 235-246. [CrossRef]

123. Wright, L.P.; Zhang, L.; Cheng, I.; Aherne, J.; Wentworth, G.R. Impacts and effects indicators of atmospheric deposition of major pollutants to various ecosystems-A review. Aerosol Air Qual. Res. 2018, 18, 1953. [CrossRef] 
124. Pilkington, M.G.; Caporn, S.J.; Carroll, J.A.; Cresswell, N.; Lee, J.A.; Ashenden, T.W.; Brittain, S.A.; Reynolds, B.; Emmett, B.A. Effects of increased deposition of atmospheric nitrogen on an upland moor: Leaching of $\mathrm{N}$ species and soil solution chemistry. Environ. Pollut. 2005, 135, 29-40. [CrossRef]

125. Kome, G.K.; Enang, R.K.; Tabi, F.O.; Yerima, B.P.K. Influence of Clay Minerals on Some Soil Fertility Attributes: A Review. Open J. Soil Sci. 2019, 9, 155-188. [CrossRef]

126. Newman, E.I. Phosphorus inputs to terrestrial ecosystems. J. Ecol. 1995, 83, 713-726. [CrossRef] 